\title{
顆粒細胞減滅性 Łアンギーナาの一剖檢例
}

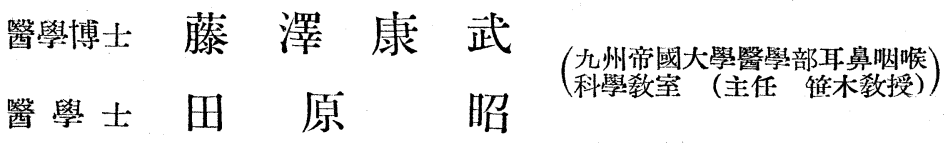

\section{緒言}

古來，壤誼性しアンギーナフ或は進行性潰瘍性 口內炎等の病理學的病名の下に總括され，報告 されて居た極めて豫後の不良なる疾患の多數例 に就て，最近血液檢查が實施されるに到つて， 其本態である全身性基礎疾患の形態が略々明か となつて來た樣である。其內特に吾人の注意を 喚起する樣になつたのは，1922年伯林の內科醫 Schultz ${ }^{1)}$ がレアグラヌロチトーゼフなる病名の 下に初めて發表し，翌年 Friedemann ${ }^{3 j}$ てより 局所々見に重きを置きて命名されたしアンギー ナ・アグラヌロチトチーカフなる疾病である.

最近數年間に顆粒細胞減減性しアンギーナフに 關する報告は歐米は勿論, 本邦に於ても亦, 著し 〈增加し，八木澤 ${ }^{5}$, 平野及び藤田 ${ }^{6)}$, 吉田 ${ }^{7,8,9}$

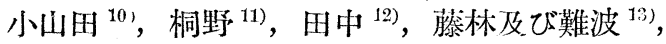
櫻井 ${ }^{15)}$ ，石坦 ${ }^{16)}$ ，柳原 ${ }^{17)}$ ，佐藤及び竹內 ${ }^{18)}$ ，國

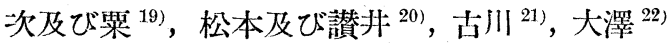
等の諸家の報告相次いで出で枚擧に㗇なき次第 である．特に樂品に因るるの多く，本邦に於て はしサルバルサンフ顆粒細胞減減性しアンギーナフ 症例が最も多く報告され，其本態に關しても， 或種の毒素或は藥品が特別なる過敏性體質を有 する者に作用した場合に，好んで骨髓の顆粒細 胞系統を侵し, 然る後, 骨髓の障碍が基礎疾患 となつて, 外界の刺戟を蒙り易き身體部位, 例 へば，口蓋扁桃腺，口腔咽頭粘膜，胃腸粘膜， 生殖器或は皮膚等に本症に特有なる壞疽性潰瘍
を形成するるのであるらと考へる學者が多くな つて來を. 故に本疾患に於ては血液檢查を施行 せずしては，其全身性基礎疾患の診斷を確定し 得ないるのであり，從つて壞疽性しアンギーナフ 或は進行性潰瘍性口內炎等に遭遇すれば, 先づ 血液檢查を施行する必要がある.

然るに本症の療法に到つては，未だ其治療方 銊を鮮明に記述せる報告はなく，單にレサルバ ルサンフに因るものは幾分豫後が可良であると 云ふのみにて，輸血，レレ線療法，自家血液療 法, レペント・ヌクレオチードา 注射 (Pentnucleotid) 等の療法が漠然と報告されて居るのみに て，吾人が本症に遭遇した場合に先づ如何なる 療法を選ぶ可尔就て迷ふとてろである.

今包余等は詳紐なる問診にも拘らず，何等原 因的樂品の注射或は投與を受けしてとなく，多 分特發性に起つた之思はれる顆粒練胞減滅性 レアンギーナフの一例を經驗し，レレフ線照射，輸 血及び自家血液注射の外に種及對症療法を試み たるも，終に救ひ得すして鬼籍に入りたる者に 就て，剖檢を行つたので，其等に就て詳細に報 告すると共に，最近報告せられた多數の文獻中 より本症に對し最も有效適切なる療法を檢索し, 本症に對する治療方針に就て簡單に附言し度い 之思子.

\section{症例}

患者 松○—, 27歲, 大工の妻. (外來番號2920).

初猃 昭和11年8月29日 (即時入院). 
主訴 高度の咽頭痛，高熱及び全身異和.

家族歷特記す可き遗傅的素因は認められない。

既往歷 生來頑健にて17歲にて初潮あり，其後月經 は不規則である，24歲にて現夫と結婚したるも未だ子 ・女はない. 約 5 年前脚氣に罹つた. 21 歲の頃外陰部に 有痛性潰瘍を生じ左側鼠䠛部淋巴腺腫脤し，整師に上 り徽毒性のものならんとでサルバルサンフ注射 8 回受 け其他内服藥及び毄筋內注射により上記の症狀は消退 した. 咽頭疾患としては今迄に $2 \sim 3$ 回咽頭痛を來たし たことあるも醫師の治療を受けず含嗽のみにて治療し $\kappa$.

現病歷 何等の認む可き誘因, 特に藥品の使用等な くして突然咽頭消を發し，自發痛は漱次增惡して夕食 攝取に困難を感ずるに到つた．柆朝惡寒戰慄と共に高 熱を發し，咽頭痛も益々增惡し來つたので患者は重篤 なる疾病に罹患した樣な感を懷き，某公立病院を訪れ 左側口蓋扁桃腺に白答ありと云将れ，細菌檢查と血液 檢查を受け，柆々日當䧎床に受診する樣に勸められて 來院した.

現症(8月29日).全身所見. 骨格, 榮養共に良好. 頜 貌は幾分苦悶の狀を呈し，皮虐は稍々瀿润し，發惨， 黃疸なく，貧血及び皮下溢血を認めない，身體各部の 淋巴腺は腫脤せず，特に莖部並に顎下淋巴腺は。觸れな い. 頸部運動に際し幾分咽頭部に疼痛を感ず。心臟及

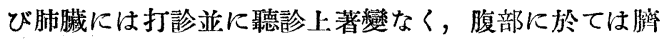
下部に輼度の壓痛するも腫脹なく，他に肝臟及び脾臟 は共に觸れない，右側腎臟は觸れるも壓痛或は腫脹な く，又下肢に浮腫もない，脈搏 102，整埕てて緊張良 好·意識明瞭, 神經系統に異常なく，棰服は咽頭痛の䈍 障碍され，便通は便秘に倾いて居る。ピルケ氏反應は 弱陽性，血液のワッセルマン氏反應，村田氏反應共に 陰性である，尿は輕度に㐿濁し，弱酸性，蚠白はしズ ルフォサリチールフ酸にて弱陽性，糖なく，レヂアッォフ

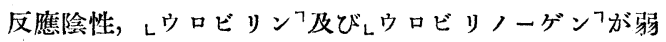
陽性であ゙る.

耳鼻咽喉科的所見 兩倒鼓膜は內引儿，左側に向ふ 鼻中隔彎曲症がある，後鼻腔には著變はない，咽頭 痛は激しく，輕度の身關緊急あり，食飭は殆ど攝取 困難にして，韾畐は 極輕度の嘶嗄を示し，又口臭が 甚だしい，右側舌骨部を外方より埾するに疼痛を訴一 る.

呐唉所見としては第一圖に示す樣に，左側口蓋扁桃
第一圖 $29 /$ VII 咽喉所見
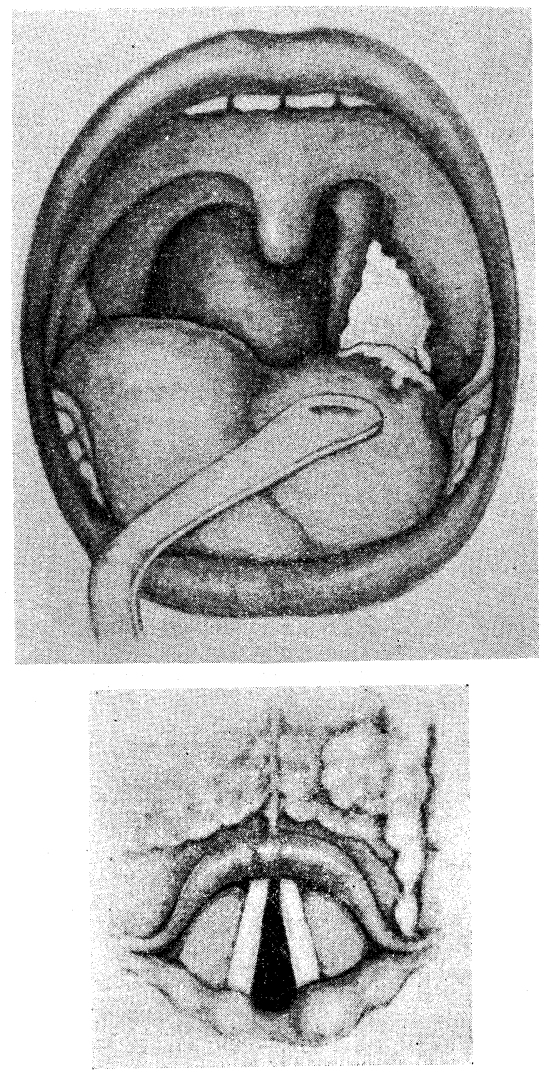

腺及び左側前口蓋引には黄白灰色䉼狀物質にて蔽はれ たる壇瘨性蛽瘍があり，壇瘨物質は分離し難く，觸れ るも出血しない，其周櫋部には輕度の發赤腫脹を認め る. 壊瘨性潰瘍は咽頭左側壁に沿ひて左側舌根扁桃腺

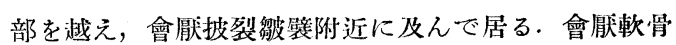
粘膜は發赤腫脤し，左側假馨帶及び左倒披裂軟骨部は 浮腫狀に腫脹し，擎帶は兩側共に荅的にて左側のみ閉

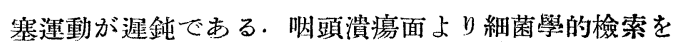
行つたのに，塗抹標本に於ては多數の連菌，雙球菌， 紡錘狀菌及び雜菌等を認めたが，レデフテリーフ菌は證 明されなかつた。文培鉴檢查に依るもんヂフテリーフ菌 は除性であり，溶連菌，肺炎雙球菌及び他の雜菌を認 めた，份文值ちに血液の培養試驗を施行したのに細菌 は陰性であつた。

此處に於て余等は全身性疾患に件ふ罯疸性 ᄂアンギ ーナフの疑ひにて直ちに血液檢查を行つたのに, 赤血 球總數 412 萬, レヘモグロビンフ含有量ザーリ一氏法にて 
$80 \%$ ，白血球總數は 4500 を算し，特に顆粒細胞系統の 激減あり，中性暂好性白血球中，分葉核僅に $1 \%$ 桿狀 核 $19 \%$ にて幼若型は認めない.ょエ?嗜好性白血球文全 く消失して居る. 然し淋巴球，大單核細胞及び移行型 は共に比率的には增加して居る.

以上の检查成績より顆粒細胞減減性レアンギーナフの 診斷の下に當日は，25\% レロヂノン $40.0 \mathrm{cc}$, 滋養洼晹 强心劑注射等を行ふと共にレオキシフルフ含嗽, 頸部の 濕布を施した.

\section{經過概略}

8月30日. 咽頭の自發痛及び曣下痛共に揸惡し, 牙關
緊急むり，流動食の骤取も困難となる、第 1 表に示す 栐な高熱を發し，時に惡寒を件ふ.左側舌骨部は輕度 の濑漫性腫脹を呈し，壓痛が著明である．左側口蓋扁

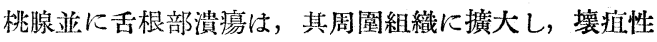
物質は帶異綠污穢色を呈して來た。血液像に於ては第 3 表に示す栐に特有なる白血球總數の激減を示し，又 特に顆粒細胞の減少は著しく，分核型中性嗜好性白血 球なく，桿狀核型も $12 \%$ に減少して居る. 然し赤血球 系統には Poikilocytose を認め，赤血數總數は395萬を 算して居る. 療法としては淡養注腸，25\%レロヂノンフ $40.0 \mathrm{cc}$ 注射，鎮痛の目的に局所に5\% レコカインフ塗布
第一表：熱型並に脈搏表

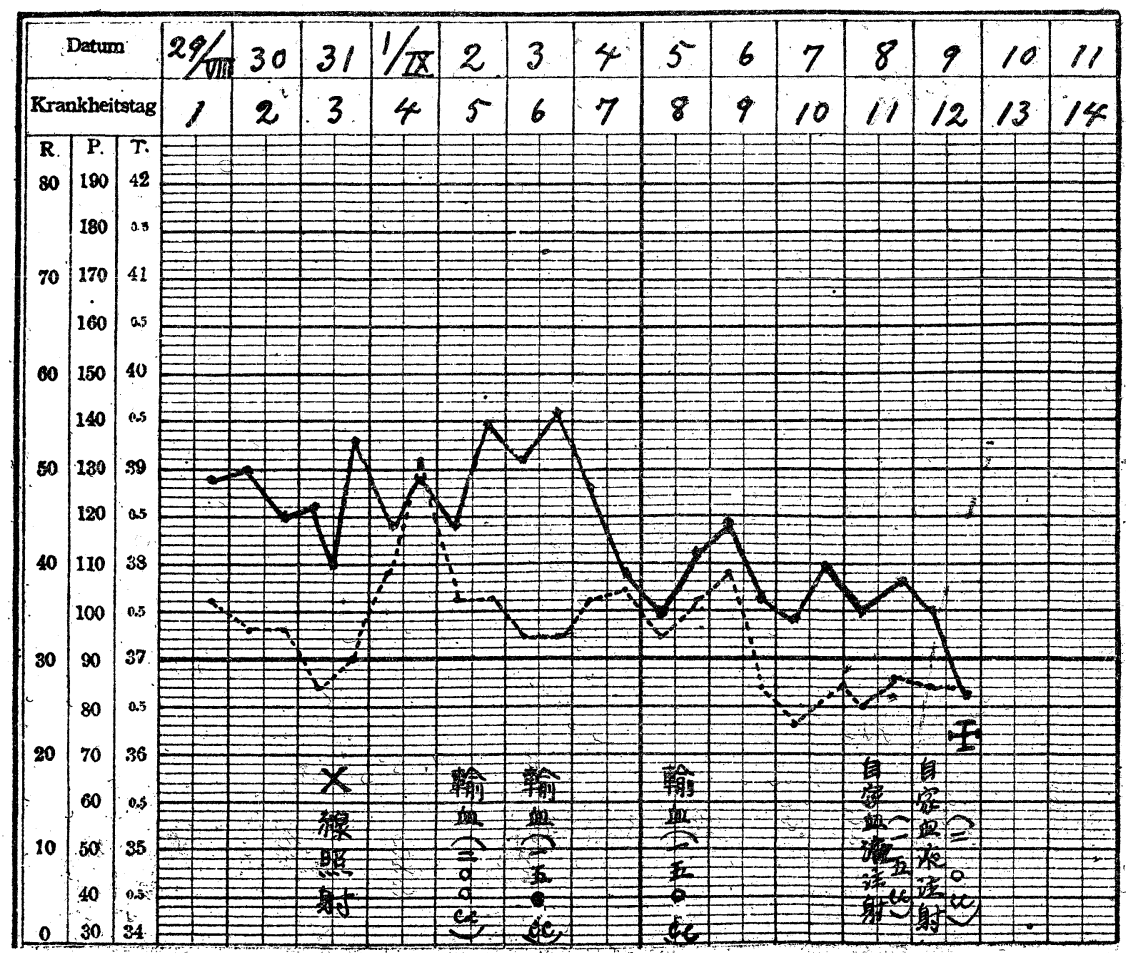

し，文レルゴール7 レメントールフ, 沃 丁等を使用した.

8 月 31 日. 鼻咽腔 に放散する激烈な る疼痛を發し，左 側顎下部及び頸部 腫脹を增惡し，咽 頭の壊瘨は周櫋部 に擴大し，馨音は 輕度の嗄馨を呈し 血液所見は前日よ り何增惡したので 午後 3 時頃レレフ線 深部療法を試み た・其放射量及び 放射部位は第二表 に示して居る.

第二表 : ᄂレフ線放射部並に放射量

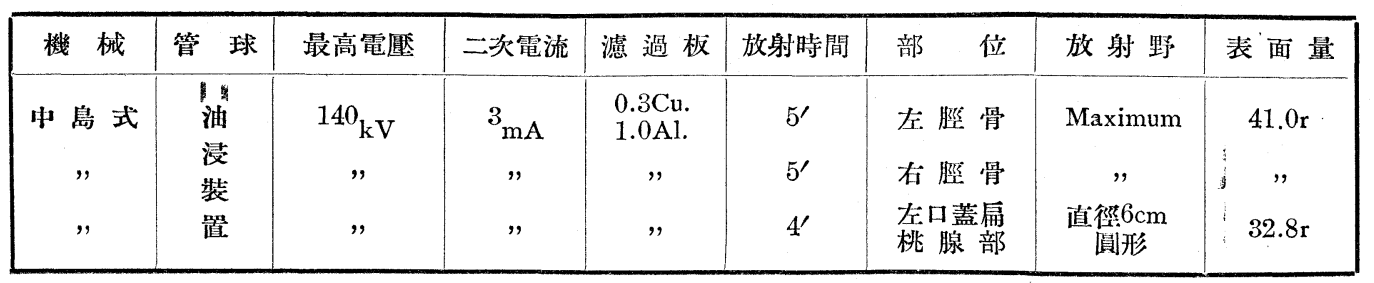


レレフ線放射㨁後，輕度の咽頭消南の增恶を見たるも， 他に全身的反應を認めなかつた．然るに柆朝午前 3 時

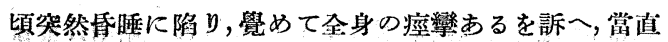

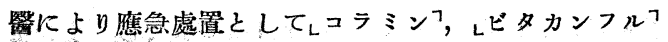
レアドレナリンフ等の强心劑及び監酸レスパミドールフ, レロヂノンフ等の注射を受け, 漸く小康を得た. 其後時 閭の經過と共に全身狀態は漸次恢復した.

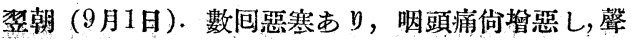
意は幾分明朗となるも，牙關緊急苗だしく，咽頭の壊

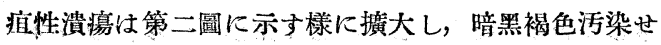
る㜔庭性物質により蔽はれて來た。

\section{第二圖 : $1 / \mathbb{X}$ 咽頭所見}
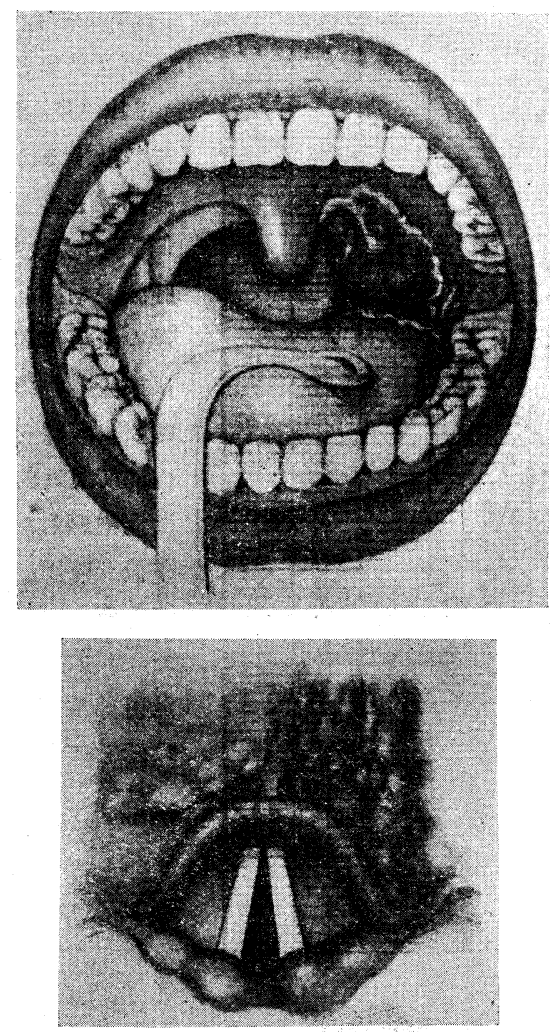

9月 2 日，何高熱持續し，脈搏頻數且つ軟弱，左側顎 下部腫脹は著明となり，厭痛䓕だしい，頸部並に额下 淋巴腺は腫脹しない，咽頭壤㾞は盆々援大の傾向を示 して居るので，間接法に從ひ，第1回輸血200cc を施行 した. 翰血後何等の反應は現はれなかつた.

9月3日．前日の輸血により全身症狀幾分輕快せるを 思はしめたるも，血液像份不良にて，局所的にも罯㨁
性潰瘍の擴大停止せず，第三圖に示す㥞に，左側軟口

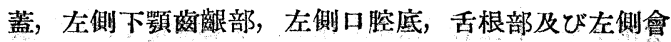

第三圖：3/IX 咽喉所見
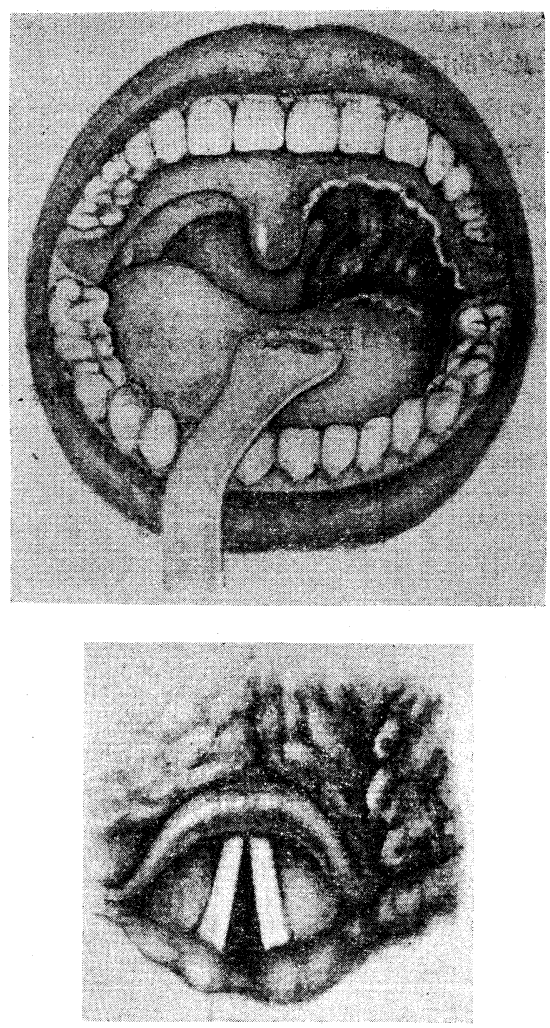

厥披裂觟譬に及ぶ，第 2 回目の血液埃養检查を行ふも 細菌は陰性であつた．本日第 2 回目の鐱血 $150 \mathrm{cc}$ 及び $5 \%$ ロデノン $100 \mathrm{cc}$ 注射を行ふ.

9 月 4 日．患者の自覺泚狀は幾分輕快したが，份左耳

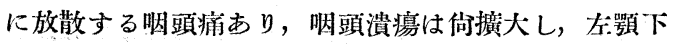
部腫脹も增加した. 血液檢查所見はレへモグロビンフ含

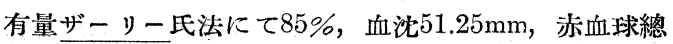
數 495 萬, 白血球總數 2600 , 內, 桿狀核中性喍好性白血 球 $28 \%$ なった。

9 月5日. 顏貌苦悶の狀を呈するも，血液檢查所見は 一進一退の狀態にて，貧血はなく，熱型は下降し來り たるも，第四圖に示す栐に願下部及び及び左側顎下部 は强度に腫脹し, 斗關緊急の営に口腔內を精查し得な い. 倚洨瘨性咽頭潰崵は擴大するを以て第 3 回目の輸 血150cc を施した。

9 月 6 日. 前日子略々同梯の全身狀態の下に咽頭潰演 
第四圖： $5 / \mathrm{X}$ 左側顎下部並に頃下部の腫脤を示す

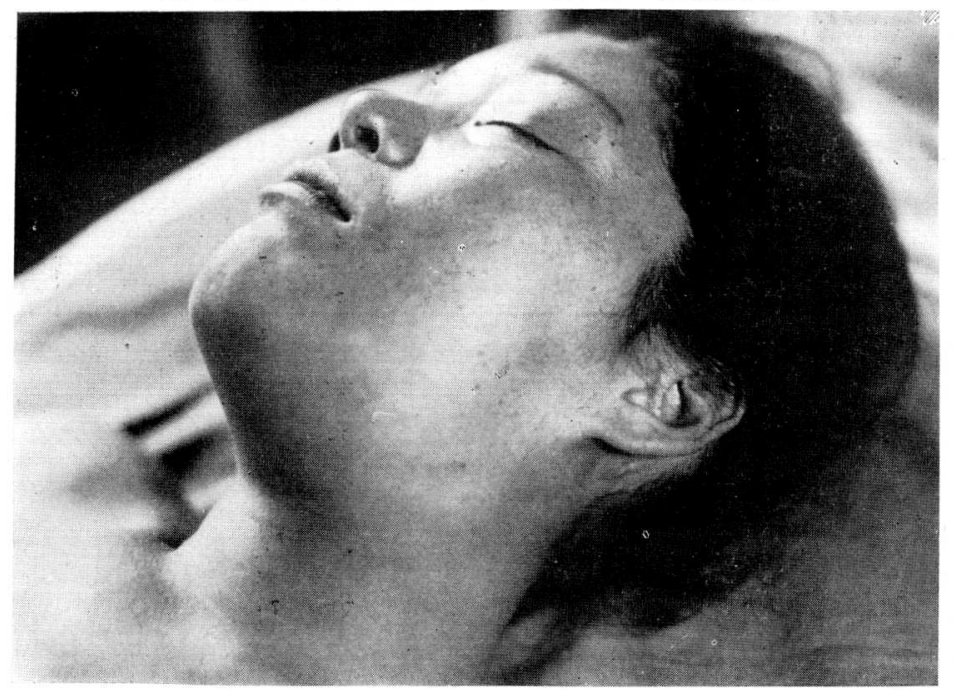

9 月8日。一見全身狀態は未だ不 良ではないが,頤下部,兩側顎下部， 甲狀軟骨附近は高度の洼潤を來た し固く, 鼾㢣及び喘鳴を發し, 咽頭 溃瘍は極度に上方，右侧及び口腔 底に向つて援大したが，末だ溃瘍 部よりの出血は認めない。口蓋垂 は全く壞店に陷り，咽頭は觀察し 得ない，赤血球泌降速度は㑣緩徐 そなりたるを以て第 1 卧日の自家 血液の $15 \mathrm{cc}$ 繁筋内に注射した。

9 月9日. 全身皮膚は幾分黄緮色 を呈し，眼結膜にも輕度の黄担が 認めら机，皮膚は筑汗著しく光鲬 を增し兩側颚下部並に臨下部の腫 脹は幾分軟化し, 舌の店牛側は强
は掹惡して來た。

9 月 7 月, 脈搏の緊張は比較的良奵にて, 呼吸も亦正

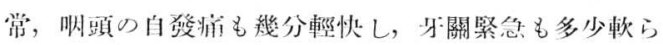

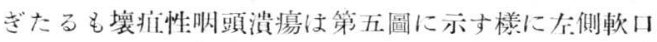

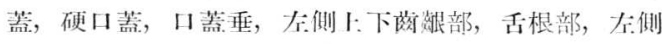

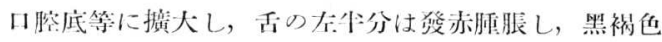

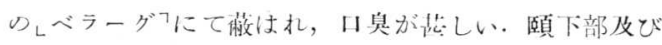

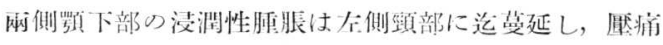

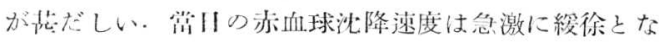
り，12.5mm を示し，豫後の不良を思はしめた。然し

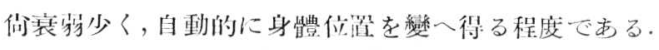

第五圖：7/IX 朋䫓所兄

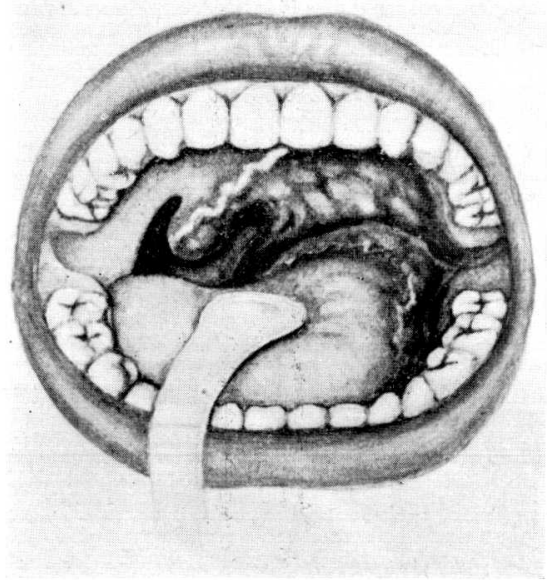

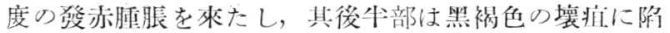

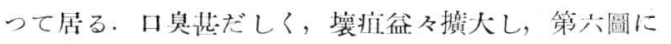

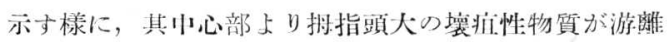
せんとし，泚血樣分泌物が多量に排出され，喘鳴は范

第六圖： $9 / \mathrm{IX}$ 呐頭所兄

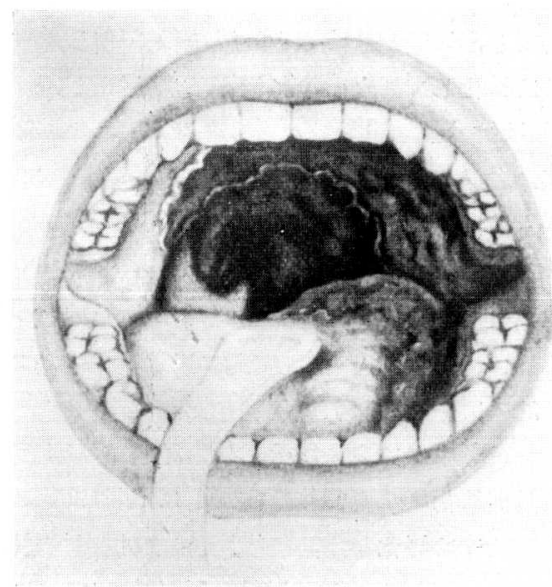

だしく，輕度の呼吸困難を訴一た。第 2 四日自家血液

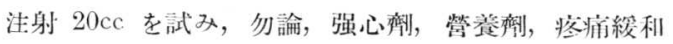
劑，沙毒劑等の投藥或は注射を持續して居たのである が，本日に到り該注射部附近に著明の皮下溢血玟を認 め，父下肢に散在性點狀皮下出血を來たした。千後 7时55分萬策を覀したるも效なく，終に心臟害弱にて鬼 籍に人つたのである. 


\section{病理解剖學的所見}

(本學部疤理學呚宝，山田學士執刀，9月10日)

病理解剖學的所見に就ては簡單にその要點のみを記 載するに止める.

心臟. 各瓣膜及び心臟內膜には著變なく，右心室は 輕度の拱張を示し,大動脈內膜は本滑H.つ光澤を有す. 心筋は赤襍色にて，顯微鏡的に輕度の心筋橫裂を認め るのみ. 肺臟. 左肺. 表面本滑，上下网葉間に㾙着な く，硬度は幾分箘加し，切呦面は液體に富み，空氣に そしい，氣管枝粘膜は輕度の充血を示し，肺門淋巴腺 は腫脹して居ない，右肺. 表面平滑，3肺葉共によく 分離し，硬さが幾分增加し，切斷面は液體及び空氣に 宫む，氣管枝粘膜父輕度に充血し，肺門淋巴腺腫脹を 認めない，組織學的には泌下性罈血が認められ，又肺 胞は滤出性液體を以て充され肺水腫の所見を呈して居 るが，未だ細胞浸潤なく，炎为性所見は認められない。 胸腺. 肉腿的には脂肪性にて, 組織學的にも亦, 腺組 織は萎縮し，增殖せる間質及び脂肪組織により置換さ れて居る. 朋㖑. 硬度咅通, 切斷面は輕度に䏦脹し, 組織敫的に腺細胞は一般に輕度の洞濁を示し，腫脹し て居る. 多數のクッペル氏細胞の核分裂を認める. 脾 㵴. 輕度に腄脤 $(15.0 \times 7.0 \times 3.6 \mathrm{~cm})$ し, 表面本滑, 硬 度は增加し, 切㫁面は赤褐色, 纖維杜系統は緻密にて 赤色䯕は軟化して居ない，組織學的には肧生中榀は消 火し, 網狀結締織細胞系統の增殖あり, 骨髓細胞及び巨 大多核白血球或はレプラズマフ細胞は比較的多數に認め られるも中性嗜好性多核白血球は殆ど認められない。 腎臟. 筒皮膜は兩側共に易く剩離され，表面平滑，星 芒狀靜脈像は鮮明にて, 切斷面は輕度の充血及び腫脤 を呈し，粲孟粘膜は允血し，諸所に點狀出血を認める. 組織學的には一般に腺上:皮細胞の洞濁腫脹を來たし， ボーマン氏訾中には少量の分泌物を認める. 副腎. 左 侧は䯣質が軟化するも右側は肉眼的に正常である.搭 臟. 肉眼的には變化なく，紆織學的には間質結締織の 輕度の增殖を認むるのみ. 狊腸. 岗腸粘膜には肉腿的 に潰瘍或は出血部を認めず，腸粘膜の淋巴滤胞に於て も胚生中榀は殆ど消火して居る・淋巴腺、身體各部の 淋巴腺は腫脹せず，腸閒膜淋巴結節に於て組織學的檢 查を試みるに，肧生中樞は消失し，淋巴組織は菱縮し， 間質結蟐織は楮殖して居り, 機能低減を物語つて居る. 淋巴組織內には淋巴細胞，骨髓細胞，巨大核白血球等 を認むるも中性嗜好性白血球は殆ど認め得ない。
骨䯕・左側上膊骨骨幹に就て組織學的檢索を試みた るに，該部に於ては脂肪髓と細胞髓とが認められるも 主として脂肪䯣より成り, 細胞䯣の部位に於ては網狀 結締織細胞の㴰殖があり，赤血球，骨䯕母細胞，骨髓 細胞等より成り，巨大多核口血球は比較的多數なるも

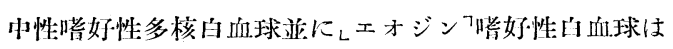
散見するのみにて，亦血球の幼若型を認め，んへマトポ エーゼフが行はれて居る.

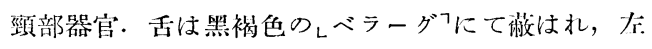
牛部，舌根部及び左侧山蓋扁桃腺は壞将に陷り，壊壮 性貲瘍は第六圖に示したと略々同樣に軟口蓋より硬口

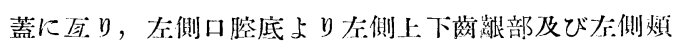
部粘膜，咽頭後壁，咽頭上壁に迄及ぶ.下方文會厥軟

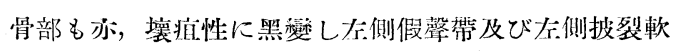
骨部々腫脹し，綠褐色を呈するも馨帶以下氣管粘膜に は著變はない.頋下部並に兩侧颚下部の腫脤部位を切

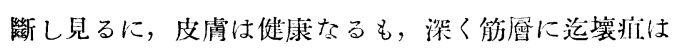
及び，該部は暗黑褐色に污染し，料狀を呈して居る. 組織學的には壞病部に於ては全組織は洧漫性に染色を

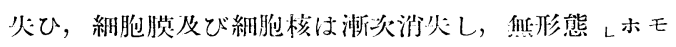

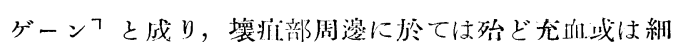

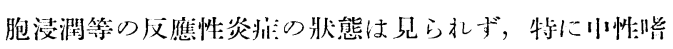
好性白血球及びレェオジンフ譄奶性自血球け極めて促少 である。

以上の病理解剖學的所兄より次の渗新在下L 得る.

1. 壤㾴性しアンギーナ?.

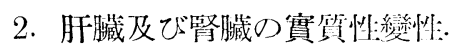

3. 輕度の脾腄.

4. 腎急の粘膜下溢血.

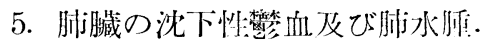

6. 輕度の右心空擴張头若.

7. 骨骨遀の顆粒綝胞造殖系統の障碍.

總 括

Schultz ${ }^{1)}$ により報告されたる定梨的或は狹義 に於けるしアグラヌロチトーゼフの症候群を檢討 して見るに，次の謢點が特有とされて居る。

（1）中年の婦人に多く棑る. 
（2）惡寒戰慄を以て始まり稽留型高熱持續 す.

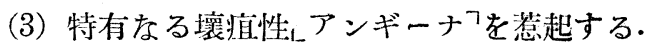

（4）全身淋巴腺腫脹はなく又肝臟及び脾臟の 腫脹を觸れぬ。

（5）黃疸を伴字.

（6）出血性素因を缺ぐ.

（7）血液所見は最も特有で白血球は著しく減 少し, 顆粒細胞も激減或は全く消失し, 淋巴細 胞は相對的に增加するが, 赤血球, 血小板, 血. 色素には殆ど變化を來たさない。

一般に顆粒細胞減隇性 數に報告されたのにも拘らず, Schultz の定型 的しアグラメロチトーゼ?に屬するものは比較的 稀なものとされて居る。然るに今, 余等の症例 を比較觀察して見るに，先づ本症例は 27 歲の婦 人に起つて居り, 疾病は咽頭痛を以て始索り,

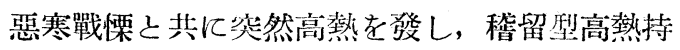
續し，患者は重篤なる疾病に踓患せる感を襄い た. 吆頭痛と共に庄側口蓋吪桃腺より始まりた る特有なる壞疽性しアンギーナフを惹起したのは 既に詳述した處である。

次に全身各部の淋巴腺腫脹に就ては最も注意 を拂つたのであるが, 全經過に互つて, 特に頸 部及び顎下部にも臨床的には淋巴腺腫脹は認め られず, 又剖檢て際して子腸間膜淋巴腺, 肺門 淋巴腺, 頸部站に腋䆚淋巴腺, 鼠蹊部淋巴腺等 の腫脹は證明されなかつた. 又肝臟及び脾臟は 臨床的には全經過に互つて觸れ得なかつたが， 特に剖檢に際して輕度の脾臟腫脹を證明した程 度である。

Schultz は黄㡺を必發の症候として記載して 居るが，本症例に於ては入院賞時は 2 因の檢尿
に際しょウロビリンフ及びレウロビリノーゲンフを 弱陽性に證明し得たるも，肉眼的には眼結膜及 び皮膚に全く黃㾝を認めなかつた. 然るに疾病 の末期に到つて眼結膜站に皮膚は輕度に黃色味 を帶び，黄疸の發現を推察し得たのである. 次 に出血性素因に就ては末期郎ち死亡前に到り皮 下注射部位に一致せる溢血及び兩側下肢に少數 の點狀皮下溢血を認め, 又剖檢に際して兩側腎 掹に粘膜下溢血を認めたのみであり，臨床的に は殆ど其全經過に互り皮下溢血も證明されず, 且つ又咽頭の壞疽性潰瘍部よりの出血も認めら れなかつたのである。

次に血液所見を觀察するに，2四試みられた 血液培養は共に陰性の結果を示して居り,レへモ グロビンフ 含有量は全經過を通じてザーリ一氏 法にて $80 \%$ 下りたるてとなく，赤血球總數も 大約 400 萬程度を上下するのみにて, 血小板に る特に減少なく, 全く赤血球系統には特别なる 障碍の起つたものとは考八られず, 殆ど認む可 き盆血はなかつたのである，然るに白血球系統 に於ては第 3 表に示す樣に著明なる病變が認め られる.郎ち白血球總數に於ては, 入院當日は 4500 にて比較的減少程度少をも翌日よりは特有 の著しき減少を來たし，入院第 8 日目に於ては 1400迄減少しそが, 然し諸家の報告に見る裳に 1000以下と成つたてとは一度も認められなかつ た. 顆粒細胞系統には白血球總數の減少に加ふ るに，著しき相對的減少が認められ，中性嗜好 性白血球中，特に分葉核型の減少は最8甚だし く全經過を通じて多くの場合, 消失して居り, 單に桿状核型が10一30\%の範圍內に於て中性啫 好性白血球を代表して居る感があり, 白血病に 認められる樣な幼若型は全く出現しなかつた。 
第三表：血液 檢查 成 績

\begin{tabular}{|c|c|c|c|c|c|c|c|c|c|c|c|c|c|c|}
\hline & & $29 / \mathrm{VIII}$ & 30 & 31 & $1 / \mathbb{X}$ & 2 & 3 & 4 & 5 & 6 & 7 & 8 & 9 & 10 \\
\hline $\begin{array}{l}\text { Lิモ } \\
\text { (ザー }\end{array}$ & 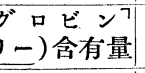 & $80 \%$ & & $80 \%$ & $85 \%$ & $80 \%$ & $80 \%$ & $85 \%$ & $90 \%$ & $89 \%$ & & $87 \%$ & $83 \%$ & \\
\hline 血 & I std & & & 73 & 71 & 80 & 60 & 60 & 38 & & 11 & 10 & 15 & \\
\hline & IIstd & & & 105 & 108 & 110 & 90 & 85 & 74 & & 28 & 26 & 41 & \\
\hline 沈 & M.S.G. & & & 62.75 & 62.5 & 67.5 & 52.5 & 51.25 & 37.5 & & 12.5 & 11.5 & 17.75 & \\
\hline 赤 血 & 球 總 數 & 412 万 & 395 万 & 389万 & 297万 & 395 万 & 380万 & 495万 & 400万 & 398万 & & 377万 & 383.2 万 & \\
\hline 白 血 & 球 總 數 & 4500 & 2200 & 1600 & 2200 & 2200 & 2000 & 2600 & 1400 & 2000 & & 3400 & 2700 & \\
\hline 中性 & 分葉 核 & $1 \%$ & - & - & - & - & - & - & $3 \%$ & - & & - & & \\
\hline 性白 & 桿狀 核 & $19 \%$ & $12 \%$ & $16 \%$ & $21 \%$ & $29 \%$ & $24 \%$ & $28 \%$ & $30 \%$ & $27 \%$ & & $20 \%$ & & \\
\hline 好球 & 幼 若 型 & - & - & - & - & - & - & - & - & - & & - & & \\
\hline Lx?喯 & 好性白血球 & - & $0.5 \%$ & $1 \%$ & - & $2 \%$ & - & - & $4 \%$ & - & & - & & \\
\hline 臨基基植 & 好性白血球 & - & - & - & - & - & - & - & - & - & & - & & \\
\hline 淋 & 巴球 & $56 \%$ & $65 \%$ & $68 \%$ & $69 \%$ & $62 \%$ & $64 \%$ & $63 \%$ & $43 \%$ & $62 \%$ & & $68 \%$ & & \\
\hline $\begin{array}{l}\text { 大單核 } \\
\text { 移 }\end{array}$ & $\begin{array}{l}\text { 細胞 及び } \\
\text { 行 型 }\end{array}$ & $22 \%$ & $22.5 \%$ & $15 \%$ & $10 \%$ & $7 \%$ & $12 \%$ & $9 \%$ & $20 \%$ & $11 \%$ & & $12 \%$ & & \\
\hline
\end{tabular}

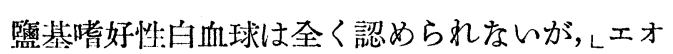
ジンフ啫好性白血球は豫後の不良なるに反し， 時々出現して居り, 又骨髓に於ても僅かながら 散見し得たのは，ょレ線放射或は輸血等に因る 骨髓刺戟に反應して出現したものと考へられる。 淋巴球は相對的には顆粒細胞の減隇々正反對に 藷しく增加し67\%に及ぶこともあつたが, 然し 絕對數に於ては多くの場合減少して居た. 佮大 單核細胞及び移行型も亦, 多くの場合相對的に は增加を示して居るが，絕對數に於ては減少し て居る. 赤血球沈降速度は入院第 3 日に於ては $62.75 \mathrm{~mm}$ を示し，第7日には $51.25 \mathrm{~mm}$ となり， 第 8 日目より急激に緩徐となり $37.5 \mathrm{~mm}$ を示し 第9日に於ては全身症彇の惡化するにも拘らず, $12.5 \mathrm{~mm}$ となり, 本症例に於ても赤血球沈降速 度の急激なる減退により豫後の不良なるを豫知 し得たのである。

以上の臨床的泣に病理解剖學的所見を通覽す るに，余等の症例は略々 Schultz の定型的 しア

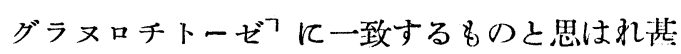
だ興味を感ずる次第である。

次に顆粒細胞減減性しアンギーナフと鑑別診斷 に來る疾患としては，

（1）出血性白血球缺乏症或は再生不能性貧血.

(2) 急性白血病.

(3) 敗血症.

（4）大單核練胞性レアンギーナフ.

(5) ᄂヂフテリー .

(6) 壞血病站飞紫斑病.

（7）惡性貧血.

等があるも，穊に吉田氏 $7,8,9)$ が顆粒細胞消失性 Łアンギーナフ(綜說) なる題目の下に詳練に鑑別 診斷に就て記載して居られるので，此處には省 略するとととする。

次に本疾患の原因に就ては多數の說があるも， 之を要するにடアグラヌロチトーゼりを獨立の疾

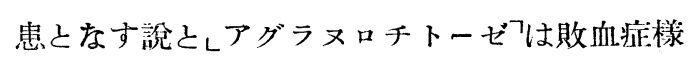
疾患の症候群に過ぎずして獨立の疾患に非ずと 
なす說の二說がある・然るに最近の交獻を涉獵 して見ると，種々の藥物即ちょアミドピリンフ เサルバルサンフ, เバルビツール酸, レルミナー

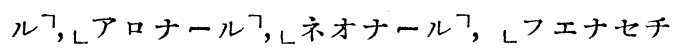

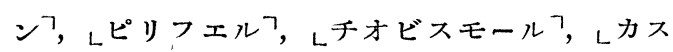

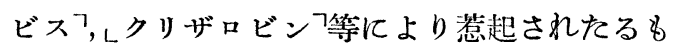
の多く, その本態としては過敏性素質を有する 者に或特種の原因物質が作倣した場合に骨髓の 顆粒細胞系統の障碍を來たすとてらの中毒性の ものであろらとの說が漸次有力となつて來た。

本邦に於ては最も多くしサルバルサン,アグラ メロチトーゼフが報告されて居るが，余等の症 例に於ては藥品の使朋を否定して居り，倘又甚 だ興味を感ずるのは，本患者に於ては既に約 6 年前驅徽療法の目的にてレサルバルサンフ注射を 8 包受けて居り, 其注射後に何等の障碍或は疾 患を惹起せずして, 今可何等認む可を誘因なく して本症に䍜患したてとであり，之により本症 例は特發性のものと思はれる。

本症の豫後は不良とされて居たが，最近數年 間にその治驗例が可なり報告せられて居る. 然 し單に對症療法のみにより特種の治療法を施行 せすして治瘑せる症例も稀ではなく，特に レサ ルバルサンフに因するものは比較的豫後が可良 の樣で治癒率も高い. 西洋の文獻には レアミド ピリンフに因るものは比較的豫後が不良であり，
又特發性のものに到つては最も踩後が不良よさ れて居る。

次に療法としても本症の本態が少不明の域を 脫しない現今適切なるものはなく，余等も亦， 本症例に遭遇して先づ如何なる方針の下に治療 法を講和可きかに困却した次第にて，余等は上 述の㥞に 射 2 包等を試みたが終に救助し得なかつたので ある・レレ線热射は余等の症例に於ては幾分强 きに失したる感あるも，輸血は常に良好に働き 居るものと推察され，自家血液注射は末期に於 て施行されたのでその效果は不明に終つた.

次に本症に對して試みられた治療方法を, 本 邦に於ては昭和 8 年以降, 外國に於ては1932年 以後の文獻144例に就て檢討したのに

(1) レペント・メクレオチード注射.

(2) 輸血.

(3) 自家血液注射.

(4) 肝臟滲出液注射.

(5) レレフ線放射.

等の順序に試みる可き價值あるものと思はれる。 余等の症例に於てもしペントヌクレオチード注 射を施行せんと思つたが，本製品を入手し得な かつたのは甚げ遺憾に思ふとてろである。

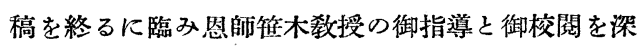
謝し份種々御嗳助を得たる病理學㜞室山田學士，常敉 室田中學士並に媲井氏に對し敬意を表す。

\section{主 要 文 獻}

1) Schultz, W : D. M. W. 48 Jg. Nr. 44, S. 1495, 1922. 1933. $\begin{array}{llll}1933 . & \text { 3) Friedemann, U.: M. Kl. } 19 \text { Jg. Nr. 41, S. 1357, 1923. } & \text { 4) Derselbe : D. M. W. } \\ 53 \text { Jg. Nr. 52, S. 2193, 1927. } & \text { 5) Yagizawa, B. (八木澤交吾) : 耳臨. 20卷, 3號, 609頁, 1927年. }\end{array}$

2) Derselbe : Zbl. Bd. 19, S. 363 , 4) Derselbe : D. M. W. 6) Hirano, A., Fujita, M. (平野贊, 藤田雅一)：耳鼻咽喉. 4卷, 2號，134-137頁，1931年. Yoshida, S. (吉田申次)：耳鼻咽䐅. 6替, 1 號，55頁，1933年. 156頁, 1933年.

9) Derselbe：耳鼻咽喉. 6怣，3號，256頁，1933年.

8) Derselbe : 耳鼻咽喉. 6卷. 2號,

10) Oyamada, $\mathbf{M}$. (小山田昌秋)：耳鼻咽喉. 6替，7號，1933年. 11 ) Kirino, K. (桐野一文)：東京醫事. 2819替，昭和 8年3月. 12) Tanaka, F. (田中文男)：實驗醫報. 240號, 昭和9年10月. M., Nanba, S. (藤林道三, 難波茂男) : 東京恶事. 2905 號，昭和9年11月. 交男): 東京醫事. 2860 號，昭和 9 年1月。 14) Tanaka, F. (田市 15) Sakurai, T. (櫻井得一) : 東京醫事. 2940 號, 昭和10年 8月. 16) Ishigaki, S. (石垣宗一郎)：滿洲醫學. 23卷, 1號, 188頁, 昭和10年7月. Yanagiwara, N. (柳原筝夫)； 内外治療. 10年，10號，927頁，昭和10年. M. (佐藤邦雄, 竹内勝) : 千葉醫學會雜誌. 14焱, 2號, 83頁, 1936. (國次尊, 粟篤吉)：東京醫事, 2985號, 昭和11年6月. 讚井憲明)：耳鼻咽喉. 9卷, 3號, 145頁, 1936. 19) Kunitsugu, I., Awa, T. 239 頁, 1936. 20) Matsumoto, S., Sanui, N. (松本周次, 21) Furukawa, H. (古川激)：耳鼻咽喉. 9卷, 3號, 22) Ohzawa, R. (大澤林之助)：東京醫事，2983號，昭和11年5月. 